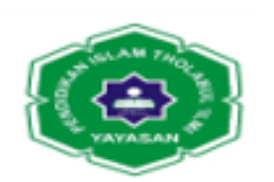

Jurnal Ilmiah METADATA

\title{
PERBUATAN MELAWAN HUKUM DALAM PERJANJIAN MULTI LEVEL MARKETING BARANG-BARANG MAKANAN, MINIMUNAN KESEHATAN DAN PERBEKALAN KESEHATAN RUMAH TANGGA DITINJAU DARI UU NOMOR 8 TAHUN 1999 TENTANG PERLINDUNGAN KONSUMEN
}

\author{
R. Juli Moertiono \\ Universitas Pembinaan Masyarakat Indonesia \\ Email: julimoertiono@gmail.com
}

\begin{abstract}
ABSTRAK
Banyak bisnis yang baru berkembang di Indonesia mengharuskan pelaku usaha dalam bisnis tersebut untuk tunduk terhadap undang-undang Perlindungan Konsumen. Hal ini berkaitan pula dengan bisnis Multi Level Marketing (MLM) yang perkembangannya di Indonesia yaitu suatu bisnis penjualan berjenjang/bertingkat, yang pastinya terdapat konsumen sebagai pendukung tumbuh dan berkembangnya bisnis tersebut. Karena suatu usaha tanpa adanya konsumen maka keberadaan usaha tersebut tidak akan berlangsung.

Dalam pembahasan penelitian ini penulis mengangkat permasalahan tentang bagaimana bentuk perlindungan terhadap pelanggaran hak-hak konsumen dalam bisnis Multi Level Marketing (MLM), bagaimana pertanggung jawaban pelaku usaha bisnis Multi Level Marketing (MLM) terhadap konsumennya

Adapun metode pengumpulan data menggunakan metode pendekatan yuridis normatif. Pendekatan yuridis normatif dilakukan dengan melihat peraturan perundang-undangan.

Berdasarkan permasalahan yang dikemukakan, maka ditarik kesimpulan bahwa perlindungan terhadap pelanggaran hak-hak konsumen dalam bisnis Multi Level Marketing (MLM), maka Distributor sebagai pelaku usaha atas konsumen multi level marketing bertanggung jawab memberikan ganti terhadap barang-barang yang tidak sesuai atau rusak yang disebabkan kesalahan pihak perusahaan kepada konsumen, serta bertanggung jawab terhadap produksi yang dihasilkannya dan bertanggung jawab atas propesinya sebagai pelaku usaha, hal ini di dukung oleh pasal-pasal tentang kewajiban pelaku usaha yang terdapat dalam Pasal $1365 \mathrm{KUH}$ Perdata dan Pasal 6 Undang-Undang Nomor 8 Tahun 1999 tentang Perlindungan Konsumen. Pertanggung jawaban pelaku usaha bisnis Multi Level Marketing $(M L M)$ terhadap konsumennya apabila salah satu pihak wanprestasi baik pihak Distributor atau anggotanya (konsumen) melakukan perbuatan ingkar janji atau tidak memenuhi prestasi sebagaimana diperjanjikan, maka dapat dituntut untuk memberikan ganti rugi akibat dari perbuatan wanprestasi tersebut.
\end{abstract}

Kata Kunci : Perbuatan Melawan Hukum, Perjanjian Multi Level Marketing Barang-Barang Makanan, Minimunan Kesehatan dan Perbekalan Kesehatan Rumah Tangga.

\section{PENDAHULUAN}




\section{Jurnal Ilmiah METADATA}

Kemajuan ekonomi terutama dalam sektor perdagangan sangat mempengaruhi kegiatan bisnis di dunia, tidak terkecuali Indonesia sebagai negara yang ingin mencapai tujuannya yaitu mensejahterakan rakyatnya. Perkembangan berbagai produk konsumen, bentuk-bentuk, jasa dan praktek bisnis lainnya dipengaruhi oleh perkembangan pesat ilmu pengetahuan dan teknologi (iptek).

Perkembangan pola kehidupan ekonomi modern yang lebih berdasarkan pada persaingan bebas dalam pemasaran barang maupun jasa dalam masyarakat yang semakin berkembang telah menimbulkan banyak permasalahan. Dengan sisitem pemasaran yang bersaing ini, pada akhirnya pihak konsumenlah yang paling dirugikan.

Kondisi yang merugikan konsumen akan menimbulkan reaksi masyarakat luas terhadap produk dari pelaku usaha baik yang bersifat lokal maupun asing menunjukkan bahwa pelaku usaha belum mampu menciptakan produk yang aman bagi pemakainya.

Banyak bisnis yang baru berkembang di Indonesia mengharuskan pelaku usaha dalam bisnis tersebut untuk tunduk terhadap undang-undang Perlindungan Konsumen. Hal ini berkaitan pula dengan bisnis Multi Level Marketing (MLM) yang perkembangannya di Indonesia yaitu suatu bisnis penjualan berjenjang/bertingkat, yang pastinya terdapat konsumen sebagai pendukung tumbuh dan berkembangnya bisnis tersebut. Karena suatu usaha tanpa adanya konsumen maka keberadaan usaha tersebut tidak akan berlangsung.

Sistem penjualan dalam bisnis Multi Level Marketing (MLM ini berbeda dengan sistem penjualan konvensional yaitu dalam Multi Level Marketing (MLM dikenal sistem penjualan langsung atau "Direct selling”, karena dalam bisnis ini penjualan dilakukan secara langsung oleh pelaku usaha kepada konsumen. Multi Level Marketing (MLM adalah cara yang efektif untuk memindahkan atau mendistribusikan produk atau jasa tanpa biaya yang biasanya berkaitan dengan biaya iklan, promosi dan pemasaran. Di Indonesia penjualan langsung bergabung dalam suatu asosiasi, yaitu Asosiasi Penjualan Langsung Indonesia (APLI). Organisasi ini merupakan organisasi KADIN (Kamar Dagang dan Industri). 


\section{을 \\ Jurnal Ilmiah METADATA}

Dalam hal ini diperlukan peran pemerintah untuk menyelesaikan sengketa, perselisihan ataupun kerugian yang terjadi pada masyarakat pemaskaian suatu produk tertentu, maka melalui sauatu lembaga seperti yang tercantum dalam Pasal 49 ayat (1) Undang-Undang Nomor 8 Tahun 1999 tentang Perlindungan Konsumen : "Pemerintah membentuk badan penyelesian sengketa konsumen di Daerah Tingkat II untuk menyelesaikan sengketa konsumen luar pengadilan”

Undang-undang Perlindungan Konsumen ini diundangkan tanggal 20 April tahun 1999 dan mulai berlaku tanggal 29 April 2000, yakni satu tahun setelah diundangkannya. Untuk itu kesiapan aparatur pemerintah di daerah dituntut untuk dapat mengantisipasi pemberlakuan Undang-undang Perlindungan Konsumen.

Dalam melaksanakan setiap kegiatan yang berhubungan dengan hukum peru diselesaikan persengketaan sesuai dengan peraturan perundangan yang berlaku, sehingga keputusan yang dihasilkan berkekuatan hukum tetap (Nurita, C., \& Lubis, M. 2019); (Nurita, C., \& Lubis, M. 2019); (Syah, D. 2019); Handayani, K., \& Siregar, M. 2019).

\section{METODE PENELITIAN}

Penelitian ini tergolong sebagai penelitian hukum normatif. Data penelitian ini bersumber dari data sekunder yang bersumber dari bahan-bahan hukum, yang terdiri dari bahan hukum primer, sekunder dan tersier. Penelitian ini menggunakan pendekatan undang-undang dan pendekatan konseptual. Analisis data dalam penelitian ini menggunakan analisis data kualitatif.

\section{HASIL DAN PEMBAHASAN}

\section{A. Tentang Perlindungan Konsumen}

\section{Perlindungan Konsumen}

Perlindungan konsumen merupakan suatu hal yang baru dalam peraturan perundang-undangan di Indonesia, meskipun sering dikemukakan mengenai perlunya peraturan perundang-undangan yang komprehensif bagi 


\section{Jurnal Ilmiah METADATA}

konsumen tersebut sudah dikemukakan sejak lama. Praktek monopoli dan tidak adanya perlindungan konsumen telah meletakkan posisi konsumen dalam tingkat yang terendah dalam menghadapi para pelaku usaha (dalam arti seluasluasnya).

Tidak adanya alternatif yang dapat di peroleh oleh konsumen telah menjadi suatu rahasia umum dalam dunia atau industri usaha Indonesia. Tidak berdayanya konsumen dalam menghadapi pelaku usaha ini jelas sangat merugikan kepentingan masyarakat.

Pada umumnya para pelaku usaha berlindung pada standard contract atau perjanjian baku yang telah ditanda-tangani oleh kedua belah pihak (antara pelaku usaha dan konsumen) ataupun melalui berbagai informasi semu yang diberikan oleh pelaku usaha kepada konsumen.

Sistim peradilan yang di nilai rumit dan cenderung berbelit-belit serta relatif mahal turut mengaburkan hak-hak konsumen dan kewajiban-kewajiban pelaku usaha, sehingga sering masyarakat sendiri tidak mengetahui dengan jelas apa yang menjadi hak-hak dan kewajiban-kewajibannya dari atau terhadap pelaku usaha dengan siapa konsumen tersebut telah berhubungan hukum.

Menurut Az. Nasution menyatakan :

Dalam Undang-Undang Nomor 8 Tahun 1999 tentang Perlindungan Konsumen yang terdiri dari 15 bab dan 65 pasal, pengertian dari perlindungan konsumen diartikan dengan cukup luas yang terwujud dalam perkataan "segala upaya yang menjamin adanya kepastian hukum untuk memberikan perlindungan kepada konsumen". ${ }^{2}$

Selanjutnya pengertian konsumen menurut Pasal 1 ayat (2) UndangUndang No. 8 Tahun 1999, dinyatakan : “Konsumen adalah setiap orang pemakai barang dan atau jasa yang tersedia dalam masyarakat, baik bagi kepentingan diri sendiri, keluarga, orang lain maupun mahluk hidup lain dan tidak untuk diperdagangkan."

Pernyataan tidak untuk diperdagangkan yang dinyatakan dalam definisi dari konsumen ini ternyata memang dibuat sejalan dengan pengertian

${ }^{2}$ Az. Nasution, Hukum Perlindungan Konsumen, Daya Widya, Jakarta, 1999, h.25. 


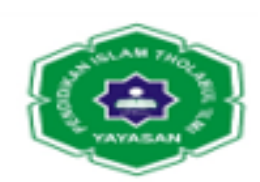

Jurnal Ilmiah METADATA

pelaku usaha yang diberikan oleh Undang-Undang No.8 Tahun 1999 Pasal 1 ayat

(3) menyebutkan yang dimaksud dengan pelaku usaha adalah:

Setiap perorangan atau badan usaha, baik yang berbentuk badan hukum maupun bukan badan hukum yang didirikan dan berkedudukan atau melakukan kegiatan dalam wilayah negara hukum Republik Indonesia, baik sendiri maupun bersama-sama melalui perjanjian menyelenggarakan kegiatan usaha dalam berbagai bidang ekonomi.

Menurut Husni Syawali dan Neni Sri Imaniyati menyatakan :

Ini berarti tidak hanya para produsen pabrikan yang menghasilkan barang dan atau jasa yang tunduk pada Undang-Undang Perlindungan Konsumen No. 8 Tahun 1999 melainkan juga para rekanan, termasuk para agen, distributor, serta jaringan-jaringan yang melaksanakan fungsi pendistribusian dan pemasaran barang dan atau jasa kepada masyarakat luas selaku pemakai dan pengguna barang atau jasa. ${ }^{3}$

\section{Hak dan Kewajiban Konsumen dan Pelaku Usaha}

Dalam rangka melindungi kepentingan konsumen, Pasal 8 UU No. 8

Tahun 1999,memberikan larangan kepada pelaku usaha dalam melaksanakan kegiatan produksi dan perdagangan barang atau jasa yaitu :

1. Tidak memenuhi atau tidak sesuai dengan standar yang dipersyaratkan dan ketentuan peraturan perundang-undangan.

2. Tidak sesuai dengan berat bersih, isi atau netto dan jumlah dalam hitungan sebagaimana yang dinyatakan dalam label atau etiket barang tersebut.

3. Tidak sesuai dengan ukuran, takaran, timbangan dan jumlah dalam hitungan menurut ukuran yang sebenarnya.

4. Tidak sesuai dengan kondisi, jaminan, keistimewaan atau kemanjuran sebagaimana dinyatakan dan label, etiket atau keterangan barang atau jasa tersebut.

5. Tidak sesuai dengan mutu, tingkatan, komposisi, proses pengolahan, gaya mode atau penggunaan tertentu sebagaimana dinyatakan dalam label atau keterangan barang atau jasa tersebut.

6. Tidak sesuai dengan janji yang dinyatakan dalam label, etika, keterangan, iklan atau promosi penjualan barang atau jasa tersebut.

7. Tidak mencantumkan tanggal kadaluarsa atau jangka waktu penggunaan atau pemanfaatan yang paling baik atas barang tersebut.

${ }^{3}$ Husni Syawali dan Neni Sri Imaniyati., Hukum Perlindungan Konsumen, Mandar Madju, Bandung, 2000, h.34. 


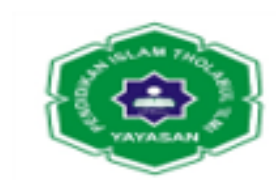

\section{Jurnal Ilmiah METADATA}

8. Tidak mengikuti ketentuan berproduksi secara halal, sebagaimana pernyataan halal yang dicantumkan dalam label.

9. Tidak memasang label atau membuat penjelasan barang yang memuat nama barang, ukuran, berat/isi bersih atau netto, komposisi, aturan pakai, tanggal pembuatan, akibat sampingan, nama dan alamat pelaku usaha, serta keterangan lain untuk penggunaan yang menurut ketentuan harus dipasang.

10. Tidak mencantumkan informasi atau petunjuk penggunaan barang dalam bahasa Indonesia sesuai dengan ketentuan perundang-undangan yang berlaku.

Secara garis besar larangan yang dikenakan dalam Pasal 8 UU No. 8

Tahun 1999 dapat dibagi ke dalam dua larangan yaitu :

a. Larangan mengenai produk itu sendiri yang tidak memenuhi syarat dan standar yang layak untuk dipergunakan atau dipakai atau dimanfaatkan oleh konsumen.

b. Larangan mengenai ketersediaan informasi yang tidak benar dan tidak akurat yang menyesatkan konsumen.

Menurut ketentuan Pasal 5 Undang-Undang Nomor 8 tahun 1999 tentang perlindungan konsumen disebutkan bahwa konsumen memiliki hak :

1. Hak atas kenyamanan, keamanan dan keselamatan dalam mengkonsumsi barang atau jasa.

2. Hak untuk memilih barang atau jasa serta mendapatkan barang atau jasa tersebut sesuai dengan nilai tukar dan kondisi serta jaminan yang dijanjikan.

3. Hak atas informasi yang benar, jelas dan jujur mengenai kondisi dan jaminan barang atau jasa.

4. Hak untuk didengar pendapat dan keluhannya atas barang atau jasa yang digunakannya.

5. Hak untuk mendapatkan advokasi, perlindungan dan upaya penyelesaian sengketa perlindungan konsumen secara patut.

6. Hak untuk mendapatkan pembinaan dan pendidikan konsumen.

7. Hak untuk diperlakukan atau dilayani secara benar, jujur, serta tidak diskriminatif.

8. Hak untuk mendapatkan kompensasi, ganti rugi atau penggantian apabila barang atau jasa yang diterima tidak sesuai dengan perjanjian atau tidak sebagaimana mestinya.

Berdasarkan hal tersebut maka masalah kenyamanan, keamanan dan keselamatan merupakan hal yang paling pokok dan utama dalam perlindungan konsumen. Sedangkan yang menjadi kewajiban dari konsumen adalah : 


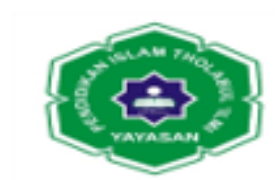

\section{Jurnal Ilmiah METADATA}

1. Beritikad baik dalam melakukan transaksi pembelian barang atau jasa.

2. Membaca atau mengikuti petunjuk informasi dan prosedur pemakaian atau pemanfaatan barang atau jasa demi keamanan dan keselamatan.

3. Membayar sesuai dengan nilai tukar yang disepakati.

4. Mengikuti upaya penyelesaian hukum sengketa perlindungan konsumen secara patut. ${ }^{4}$

Untuk menciptakan kenyamanan berusaha bagi para pelaku usaha dan sebagai keseimbangan atas hak-hak yang diberikan kepada konsumen maka pelaku usaha memiliki hak :

1. Mendapatkan perlindungan hukum dari tindakan konsumen yang beritikad tidak baik.

2. Menerima pembayaran yang sesuai dengan kesepakatan mengenai kondisi dan nilai tukar barang atau jasa yang dipergunakan.

3. Melakukan pembelaan diri sepatutnya di dalam penyelesaian hukum sengketa konsumen.

4. Rehabilitasi nama baik apabila tidak terbukti secara hukum bahwa kerugian konsumen tidak diakibatkan oleh barang atau jasa yang diperdagangkan. ${ }^{5}$

Sebagai konsekuensi dari hak konsumen yang telah diuraikan maka pelaku usaha dibebankan kewajiban :

a. Beritikad baik dalam melakukan kegiatan usahanya.

b. Memberikan informasi yang benar, jelas dan jujur mengenai kondisi dan jaminan barang atau jasa serta memberikan penjelasan penggunaan, perbaikan dan pemeliharaan.

c. Memperlakukan atau melayani konsumen secara benar, jujur serta tidak diskriminatif.

d. Menjamin mutu barang atau jasa yang di produksi atau diperdagangkan berdasarkan ketentuan stand ar mutu barang dan jasa yang berlaku.

e. Memberikan kesempatan kepada konsumen untuk menguji atau mencoba barang dan jasa serta memberi jaminan atas barang yang dibuat atau diperdagangkan.

f. Memberi kompensasi, ganti rugi atau penggantian kerugian akibat penggunaan, pemakaian dan pemanfaatan barang atau jasa yang diperdagangkan. ${ }^{6}$

${ }^{4}$ Sudaryatmo., Hukum dan Advokasi Konsumen, PT. Citra Aditya Bhakti, Bandung,

${ }^{5}$ Zumrotin K. Susilo., Penyambung Lidan Konsumen, YLKI, Jakarta, 1996, h.3

${ }^{6}$ Shidarta., Perlindungan Konsumen Indonesia, PT. Grasindo, Jakarta, 2000, h.28 


\section{(ㄷ) \\ Jurnal Ilmiah METADATA}

\section{Ketentuan Pencantuman Klausula Baku}

Dalam era globalisasi, pembakuan syarat-syarat perjanjian merupakan mode yang tidak dapat dihindari. Bagi pengusaha mungkin ini merupakan cara mencapai tujuan ekonomi yang efisien, praktis dan cepat.

Setelah terjadi revolusi industri di Eropa Barat pada abad ke-19, kebutuhan perjanjian standar makin berkembang. Jumlah transaksi perdagangan makin mengikat, konsentrasi modal makin besar, sehingga penggunaan kontrak-kontrak baku makin mendesak. Pada abad ke-20 pembakuan syarat-syarat perjanjian makin meluas. Terjadilah penumpukan modal besar pada kelompok golongan ekonomi kuat yang disebut kapitalis. Golongan kapitalis ini muncul sebagai pihak pengusaha yang menyediakan jasa menawarkan produksi atau jasa mereka kepada masyarakat konsumen. Sehingga konsumen hanya dihadapkan pada dua pilihan.

Jika konsumen membutuhkan produksi atau jasa yang ditawarkan kepadanya, maka ia harus menyetujui perjanjian tersebut dengan syarat-syarat standar yang sodorkan kepadanya. Dalam bahasa inggris diungkapkan dengan sebutan "take it". Jika konsumen tidak menyetujui syarat-syarat standar yang ditawarkan tersebut, ia menolak mengikatkan diri dalam perjanjian dengan pengusaha yang bersangkutan. Dalam bahasa inggris diungkapkan dengan sebutan "leave it".

Istilah klausula baku berasal dari bahasa Belanda yaitu standard contract yang dalam bahasa Inggris disebut sebagai standarized contraact atau standard agreement. Kaata baku atau standar artinya tolak ukur yang dipakai sebagai patokan. Dalam hubungan ini, perjanjian baku artinya perjanjian yang menjadi tolak ukur yang dipakai sebagai patokan atau pedoman bagi setiap konsumen yang mengadakan hubungan dalam perjanjian baku ialah meliputi model, rumusan dan ukuran. ${ }^{7}$

Perjanjian standar atau klausula baku timbul sesuai dengan perkembangan kebutuhan masyarakat. Tuntutan masyarakat akan efisien dan kepraktisan mengakibatkan pemakaian perjanjian standar terus mengalami perkembangan.

Menurut Pasal 18 UU No. 8 Tahun 1999 disebutkan tentang ketentuan pencantuman klausula baku yaitu :

${ }^{7}$ Abdulkadir Muhammad., Perjanjian Baku Dalam Praktek Perusahaan Perdagangan, PT. Citra Aditya Bhakti, Bandung, 1992,, h.6. 


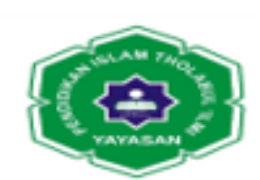

\section{Jurnal Ilmiah METADATA}

(1) Pelaku usaha dalam menawarkan barang dan/atau jasa yang ditujukan untuk diperdagangkan dilarang membuat atau mencantumkan klausula baku pada setiap dokumen dan/atau perjanjian apabila :

a. Menyatakan pengalihan tanggung jawab pelaku usaha

b. Menyatakan bahwa pelaku usaha berhak menolak menyerangkan kembali barang yang dibeli konsumen

c. Menyatakan bahwa pelaku usaha berhak menolak penyerahan kembali uang yang dibayarkan atas barang dan/atau jasa yang dibeli oleh konsumen

d. Menyatakan pemberian kuasa dari konsumen kepada pelaku usaha baik secara langsung maupun tidak langsung untuk melakukan segala tindakan sepihak yang berkaitan dengan barang yang dibeli oleh konsumen secara angsuran.

e. Mengatur perihal pembuktian atas hilangnya kegunaan barang atau pemanfaatan jasa yang dibeli oleh konsumen

f. Memberi hak kepada pelaku usaha untuk mengurangi manfaat jasa atau mengurangi harta kekakayaan konsumen yang menjadi objek jual beli jasa

g. Menyatakan tunduknya konsumen kepada peraturan yang berupa aturan baru, tambahan dan lanjutan dan/atau pengubahan lanjutan yang dibuat sepihak oleh pelaku usaha dalam masa konsumen memanfaatkan jasa yang dibelinya

h. Menyatakan bahwa konsumen memberi kuasa kepada pelaku usaha untuk pembebanan hak tanggungan, hak gadai atau hak jaminan terhadap barang yang dibeli oleh konsumen secara angsuran.

(2) Pelaku usaha dilarang mencantumkan klausula baku yang letak dan bentuknya sulit terlihat atau tidak dapat dibaca secara jelas, atau yang pengungkapannya sulit dimengerti.

(3) Setiap klausula baku yang telah ditetapkan oleh pelaku usaha pada dokumen atau perjanjian yang memenuhi ketentuan sebagaimana dimaksud pada ayat (1) dan ayat (2) dinyatakan batal demi hukum

(4) Pelaku usaha wajib menyesuaikan klausula baku yang bertentangan dengan undang-undang ini.

\section{B. Tinjauan Tentang Multi Level Marketing}

\section{Pengertian dan Prinsip-Prinsip Multi Level Marketing}

MLM adalah singkatan dari "Multi Level Marketing". Multi berarti banyak dan level berarti jenjang atau tingkat, sedangkan marketing artinya pemasaran. Jadi "Multi Level Marketing", adalah pemasaran yang berjenjang banyak. Dalam pengertian “marketing”, sebenarnya mencakup menjual. Selain 


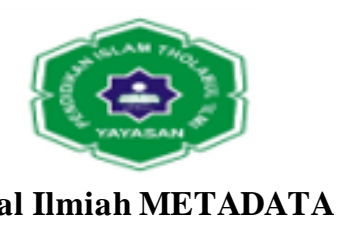

menjual, dalam marketing juga banyak aspek yang berkaitan antara lain yaitu produk, harga, promosi, distribusi dan sebagainya.

Menurut philip Kolter, bahwa "marketing (pemasaran) sebagai proses sosial dan managerial yang membuat individu dan kelompok untuk memperoleh apa yang mereka butuhkan serta inginkan lewat penciptaan dan pertukaran timbal balik produk dan nilai dengan orang lain." 8

"Di Amerika konsep dalam bisnis Multi Level Marketing telah dikembangkan jauh lebih luas, sampai hampir setiap barang atau jasa dapat diperoleh melalui Multi Level Marketing. Ini merupoakan bisnis multinasional, yang menyangkut bidang perdagangan dan melibatkan jutaan orang". 9

"Bagi pabrikan, Multi Level Marketing hemat biaya dan meningkatkan volume penjualan yang terus menerus tanpa harus mengeluarkan biaya iklan dan gaji staf penjualan tetap. Kadang ada juga yang mengatakan bahwa Multi Level Marketing itu adalah bisnis penjualan langsung yaitu "Direct Selling". ${ }^{10}$

Menurut Tarmizi Yusuf, masalah produk sangat menentukan keberhasilan sebuah perusahaan Multi Level Marketing ditinjau dari segi produk antara lain sebagai berikut :

a. Ada produk yang dijual. Inilah kunci suatu Multi Level Marketing, tanpa produk berarti bukan Multi Level Marketing. Produk disini dalam bentuk barang atau jasa. Multi Level Marketing adalah suatu sistem penjualan, bila tidak ada penjualan, sudah dipastikan bahwa itu bukan Multi Level Marketing.

b. Produk yang berkwalitas. Produk tanpa kwalitas sulit dipasarkan, padahal keberhasilan suatu perusahaan Multi Level Marketing adalah peningkatan onzet penjualan. Kalau produk tidak berkwalitas, maka omzet sulit berkembang. Karena sifat produk Multi Level Marketing adalah ekslusif, maka harga yang tinggi tidak akan menjadi masalah.

c. Harga produk wajar. Biasanya produk yang dipasarkan melalui Multi Level Marketing berbeda dengan produk biasa. Perbedaan ini yang mempunyai daya tarik. Namun demikian harga harus tetap wajar dan sesuai dengan kualitas. ${ }^{11}$

\footnotetext{
${ }^{8}$ Philip Kotler and Bary Armstrong., Dasar-Dasar Pemasaran (principle of Marketing), Prenhallindo, Jakarta, 1997 hal.6

${ }^{9}$ Peter J. Clotheir., Meraup Uang Dengan Level Marketing, Gramedia Utama, Jakarta, 1996, h.13.

10 Tarmizi Yusuf., Strategi MLM Secara Cerdas dan Halal, PT. Alex Media Komputindo, Jakarta, 2000,h.7

${ }^{11}$ Ibid, h. 21 .
} 


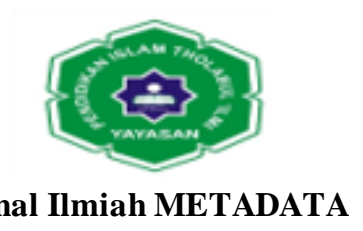

\section{Sistem Jual Beli Barang Melalui Multi Level Marketing.}

Sebagaimana sebuah bisnis, Multi Level Marketing memenuhi persyaratan sebagai bisnis murni, yaitu bisnis pemasaran. Bisnis pada dasarnya merupakan suatu kegiatan individu atau organisasi untuk menghasilkan suatu produk kemudian menjualnya untuk mendapatkan keuntungan. "Ada tiga kata kunci dalam menjalankan bisnis Multi Level Marketing, yaitu produk, menjual dan keuntungan. Itu sebabnya sampai saat ini kalau ada bisnis tanpa produk maka bisnis itu diragukan". ${ }^{12}$

Begitu halnya dengan bisnis Multi Level Marketing yang juga harus ada produknya berupa barang dan/atau jasa. Tanpa produk bukanlah Multi Level Marketing, boleh jadi arisan berantai atau penggandaan uang dan sebagainya.

Penjualan dalam bisnis Multi Level Marketing terbagi dua, yaitu kepada orang lain dan kepada diri sendiri. Penjualan dalam Multi Level Marketing merupakan unsur "marketing", yang penting ada produk yang bergerak dari produser ke konsumen. Tanpa pergerakan ini berarti bukan Multi Level Marketing, karena yang dipentingkan di sini pergerakan produk dari produsen ke konsumen.

Pada saat krisis di mana seorang sulit mendapatkan kekayaan secara wajar, jangankan kekayaan, untuk hidup sehari-hari saja sulit, maka akan sangat mudah tertarik apabila ada suatu bisnis yang menjanjikan kekayaan. Banyak perusahaan yang berkedok Multi Level Marketing yang menjanjikan mendapatkan kekayaan dengan cara yang mudah atau dengan kata lain tanpa adanya usaha akan mendapatkan keuntungan yang berlipat ganda misalnya perusahaan yang berkedok bisnis Multi Level Marketing yaitu dengan sistem penggandaan uang kepada masyarakat luas secara singkat.

Multi Level Marketing yang baik biasanya bergabung dengan APLI (Asosiasi Penjualan Langsung Indonesia) setiap perusahaan yang ingin bergabung dengan APLI harus teliti dulu apakah memenuhi persyaratan sebagai perusahaan yang bergerak dalam penjualan langsung, dalam hal ini "Multi Level Marketing".

${ }^{12}$ Buhari Alma., Pengantar Bisnis, Al-Fabeta,Bandung, 1998, h.13. 


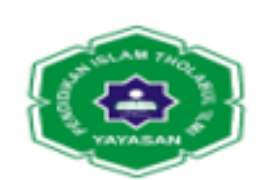

Jurnal Ilmiah METADATA

Bagi perusahaan yang sudah bergabung dengan APLI (Asosiasi Penjualan Langsung Indonesia) berarti sudah melewati masa seleksi yang ketat. Sebaliknya bagi perusahaan yang mengaku sebagai perusahaan Multi Level Marketing, tidak akan mendaftar pada APLI (Asosiasi Penjualan Langsung Indonesia) misalnya : BMA yang bergerak dalam sistem penggandaan uang yang menamai dirinya dalam bisnis Multi Level Marketing.

\section{Perlindungan Terhadap Pelanggaran Hak-Hak Konsumen Dalam Bisnis Multi Level Marketing (MLM)}

Sebelum penulis membahas masalah perlindungan terhadap pelanggaran hak-hak konsumen dalam bisnis Multi Level Marketing (MLM), maka harus diketahui terlebih dahulu bentuk dari perjanjian tersebut.

Menurut Tarmizi Yusuf disebutkan bahwa :

Perjanjian antara pelaku usaha dengan distributor sebelumnya telah dipersiapkan oleh pelaku usaha dalam bentuk formulir, dan seorang distributor dapat langsung menand atangani perjanjian tersebut, yang artinya bahwa distributor itu menerima isi perjanjian tersebut. Isi dari perjanjian itu akan mengikat distributor untuk tidak berbuat sesuatu atau dapat berbuat sesuatu yang diperbolehkan oleh pelaku usaha serta bentuk sanksi dari pelanggaran atas kesalahan dari distributor tersebut. ${ }^{13}$

Dengan demikian perjanjian antara pelaku usaha dengan distributor adalah berbentuk perjanjian baku artinya bahwa distributor tidak ikut serta dalam pembuatan perjanjian tersebut.

Binis Multi Level Marketing ini pada dasarnya dalam melakukan bisnisnya dengan sistem secara langsung. Hal ini sesuai dengan pendapat Peter J. Clothei yang disebutkan :

Sebelumnya dijelaskan bahwa syarat utama dakam menjalankan sebuah bisnis MLM adalah adanya barang/objek yang diperdagangkan dan jumlah barang tersebut harus banyak dan bervariasi artinya bukan terfokus untuk satu jenis barang, misalnya : jenis kosmetik, peralatan rumah tangga, makanan suplemen, dan sebagainya. Cara penjualan dalam bisnis MLM yaitu dengan penjualan secara langsung artinya dari pelaku usaha langsung dijual kepada konsumen tidak melalui dengan penjual eceran, dimana kedudukan konsumen disini tidak hanya sebagai konsumen akhir tetapi juga sebagai konsumen antara. Setiap produk-produk yang disediakan oleh

\footnotetext{
${ }^{13}$ Tarmizi Yusuf, Op.Cit, h.64
} 


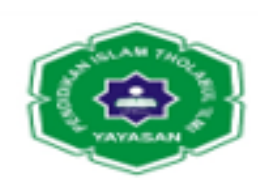

\section{Jurnal Ilmiah METADATA}

perusahaan MLM, akan dijual kepada konsumen dengan harga yang telah ditentukan oleh pihak pelaku usaha dan ketentuan harga tersebut tidak dapat di ganti oleh seorang distributor, artinya distributor tidak dapat menaikkan atau menurunkan harga yang telah ditentukan tersebut. Dalam MLM dapat dibagi menjadi :

1. Harga distributor yaitu harga jual dari perusahaan MLM kepada anggota dari MLM (distributor)

2. Harga konsumen yaitu harga dari distributor kepada bukan anggota dari MLM (konsumen akhir). ${ }^{14}$

Dalam perjanjian bisnis multi level marketing sebenarnya resiko yang ditanggung para pihak sangat minim. Menurut Endang Setyowati disebutkan bahwa :

Dalam menjalankan bisnis MLM dapat dikatakan minim sekali mendapat resiko tapi didalam hal ini seorang harus berhati-hati dalam memilih atau bergabung dalam bisnis MLM disebabkan telah banyak orang yang terkecoh menjalankan bisnis yang berkedok MLM tetapi di dalamnya hanyalah sebuah bisnis pengagandaan uang, mis : BMA yang pernah terjadi di Medan. Seorang yang telah masuk dalam keanggotaan MLM dan menjadi seorang distributor tidak mempunyai kewajiban terhadap perusahaan MLM, hanya saja setiap orang yang ingin mendapatkan komisi/bonus lebih dari penjualan produk yang ditawarkan oleh perusahaan mempunyai keharusan menjual dengan target penjualan yang telah ditentukan. Resiko terhadap barang yang rusak, seorang distributor dapat meminta pertanggung jawaban kepasda perusahaan. ${ }^{15}$

Bisnis Multi Level Marketing, jika seorang yang telah menjadi anggota dari bisnis tersebut tentunya akan mendapatkan komisi atau bonus dari hasil penjualan produk-produk yang dipasarkan oleh distributor.

Adapun sistem pembagian bonus atau komisi adalah sebagai berikut :

Pertama-tama kita dapat memisahkan terlebih dahulu pemakaian kata bonus dan komisi, dapat dikatakan bahwa seorang distributor yang baru bergabung belum mendapat bonus, seorang baru mendapat bonus apabila te;ah melakukan penjual atau prestasi melebihi target atau mempunyai jaringan yang luas dan jaringan bersifat aktif.

Komisi yang didapat dari seorang distributor :

1. Komisi yang didalam dari selisih harga beli (diskon) melalui perusahaan dengan harga beli melalui distributor lain.

2. Komisi dari pengembangan kelompok (jaringan), komisi ini didapat bukan semata-mata atas penambahan jumlah jaringan saja akan tetapi berdasarkan atas prestasi yaitu "melakukan transaksi jual beli". Ini wajar

${ }^{14}$ Peter J. Clothei, Op.Cit, h.75

${ }^{15}$ Ibid, h. 76 


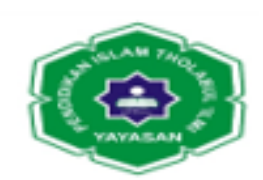

\section{Jurnal Ilmiah METADATA}

karena komisi bukan diambil dari uang pendaftaran melainkan dari omzet penjualan kelompok distributor bersangkutan. Semakin besar omzet kelompok, semakin besar pula komisinya.

3. Royalti yaitu komisi yang didapat seseorang karena telah berjasa mengenalkan bisnis kepada orang lain, ia adalah penyambung atau perantara. Apabila banyak distributor yang bergabung kemudian bergerak dan sukses, sepantasnyalah mendapatkan suatu jasa.

Bonus yang disediakan oleh perusahaan MLM bermacam-macam jenisnya diantaranya : bonus kendaraan, bonus wisata ke manca negara, bonus rumah dan sebagainya. Bonus di dapat apabila seorang distributor telah mencapai tingkat penjualan atau prestasi tertentu, sehingga semakin tinggi prestasi semakin besar pula bonus yang akan diterima. ${ }^{16}$

Komisi/bonus dari perusahaan yang disediakan kepada distributor yaitu seperti bahwa dalam sistem jual beli dalam bisnis MLM terdapat beberapa mata rantai yang terlewatkan yang diantaranya :

1. Dalam mempromosikan dan mengiklankan sejumlah produk perusahaan MLM tidak perlu mengiklankan melalui TV dan mass media lainnya yang banyak memakan biaya. Tetapi para distributor yang menjadi bintang iklan sebagai orang yang melakukan demonstrasi atau memperagakan produk yang dipasarkan. Dengan demikian perusahaan MLM dapat menghemat biaya pemasaran dari sektor iklan ini, kemudian dana iklan itulah yang dialokasikan untuk komisi dan bonus.

2. Proses penjualan yang langsung dari perusahaan MLM didistribusikan melalui para distributor dan ditributor sendiri sebagai konsumen. Dengan demikian dapat menghemat antara $20 \%$ - 30\% biaya. Kalau dijumlahkan penghematan iklan dan penghematan dari pemutusan jalur distribusi, bisa mencapai $40 \%$ - 50\%. Maka sangatlah wajar dari jumlah itu yang dibagikan sesuai dengan prestasi masing-masing distributor. ${ }^{17}$

Setelah diketahui bentuk dan sistem penjualan dalam bisnis Multi Level Marketing, maka selanjutnya dibahas masalah tanggung jawab dalam bisnis tersebut.

Tanggung jawab seseorang atas segala perbuatannya akibat dari kelalaian atau kurang hati-hati, tanggung jawab ini dikenal dalam hukum perdata istilah “prestasi”. Ketentuan dalam Pasal 1365 KUH Perdata yang menyebutkan bahwa tiap perbuatan melanggar hukum yang menimbulkan kerugian kepada orang lain, mewajibkan orang lain yang karena kesalahannya menerbitkan kerugian itu,

${ }^{16}$ Tarmizi Yusuf, Op.Cit, h.81

${ }^{17}$ Ibid, h.83 


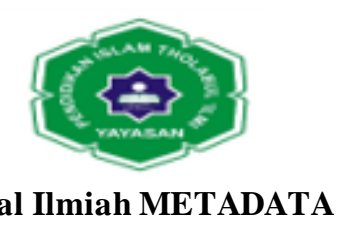

mengganti kerugian tersebut. Dari pasal ini dapat disimpulkan bahwa setiap orang yang dirugikan oleh peristiwa kelalaian, kurang hati-hati, berhak mendapatkan ganti rugi (konpensasi) atas kerugiannya itu. Tetapi untuk mendapatkan ganti rugi tersebut undang-undang membebankan pembuktian kesalahan orang lain dalam peristiwa tersebut kepada mereka yang menggugat ganti rugi.

Salah satu alasan meluasnya tanggung jawab adalah praktek penjualan modern. Sekarang ini pengecer pada pokoknya berfungsi sebagai penyalur barang-barang yang telah dikemas sebelumnya dan kemudian diiklankan oleh pelaku usaha atau produsen. Ini memperluas cakupan tanggung jawab produk sehingga mencakup perusahaan pembuat (pelaku usaha) dan pihak-pihak lain dalam mata rantai distribusi. Perluasan tanggung jawab produk hingga mencakup pabrik pembuat, bagaimana pun tidak banyak mengurangi tanggung jawab penjual kepada pembeli. Hal ini justru memperluas dasar tanggung jawab dengan pengembangan dan penerapan prinsip-prinsip hukum baru.

Tanggung jawab perusahaan dan penjual barang atas produk yang cacat atau gagalnya kinerja dengan layak, bisa didasarkan atas : kelalaian, salah persentasi, pelanggaran kewajiban menurut undang-undang, garansi, tanggung jawab mutlak atas kerugian.

Dalam bisnis Multi Level Marketing menurut Tarmizi Yusuf, bahwa distributor center $(D C)$ mempunyai tanggung jawab yaitu :

Sebuah distributor center harus mempunyai tanggung jawab secara penuh, dalam arti bahwa distributor center harus terus menyampaikan setiap menyampaikan setiap informasi bagi konsumennya baik itu informasi tentang kwalitas produk maupun informasi mengenai perkembangan perusahaan. Mengenai pengaduan atas kerugian atau kerusakan barang dari pihak konsumen, maka konsumen dapat mengembalikan barang tersebut ke distributor center kemudian distributor center tersebut akan mengirimkan pengaduan tersebut kepada kantor pusat. ${ }^{18}$

\section{Pertanggung Jawaban Pelaku Usaha Bisnis Multi Level Marketing (MLM)}

\section{Terhadap Konsumennya}

${ }^{18}$ Ibid, h.89 


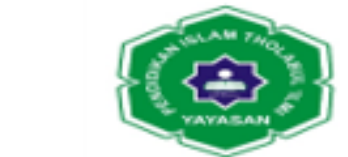 \\ Jurnal Ilmiah METADATA}

Koran-koran baik koran ibukota maupun koran daerah termasuk pemberitaan televisi, sangat ramai membicarakan MLM. Hujatan terhadap MLM datang bertubi-tubi. Kelompok yang sudah dari awal yang sudah apriori ikut nimbrung menghujat secara keras.

Kasus New Era 21 yang juga timbul di Medan dan banyak lagi kasuskasus lainnya yang jelas banyak merugikan para anggotanya. Sebagian besar anggotanya menolak untuk menutup perusahaan tersebut dengan alasan bahwa perusahaan yang berkedok MLM ini tidak merugikan bahkan memberikan kesempatan untuk mendapat keuntungan. Ada peserta yang bermodal Rp 200.000.000,- (dua ratus juta rupiah) nantinya akan mendapatkan keuntungan Rp 1 miliar, orang tersebut sudah pasti merasa diuntungkan.

Pada dasarnya kegiatan tersebut bukan bisnis MLM, hanya cara mengembangkan dan mencari anggotanya mirip seperti yang dilakukan dalam bisnis MLM yaitu mengajak orang lain untuk bergabung kemudian orang tersebut akan mengajak orang lain lagi.

Bermunculannya kasus-kasus yang berkedok bisnis MLM dan menjerat masyarakat sebagai pihak konsumen merupakan bukti bahwa ketidak tegasan pemerintah menyikapi permasalahan perlindungan konsumen ini, dan dikarenakan juga tidak adanya pengawasan langsung oleh pemerintah.

Hukum Perlindungan Konsumen merupakan bagian dari Hukum Konsumen yang memuat asas-asas lalu kaidah-kaidah yang bersifat mengatur dan menganung sifat yang melindungi kepentingan konsumen.

Maka dengan keluarnya UU No. 8 Tahun 1999 tentang Perlindungan Konsumen diharapkan dapat dijadikan salah satu senjata yang sangat berharga bagi konsumen untuk mendapatkan suatu kepastian hukum, sebaliknya bagi pihak produsen juga perlu berhati-hati.

Dalam Pasal 30 UUPK menyebutkan :

1. Pengawasan terhadap penyelenggaraan perlindungan konsumen serta penerapan ketentuan peraturan perundang-undangannya diselenggarakan oleh pemerintah, masyarakat, dan lembaga perlindungan konsumen swadaya masyarakat. 


\section{을 \\ Jurnal Ilmiah METADATA}

2. Pengawasan oleh pemerintah sebagaimana yang di maksud pada ayat (1) dilaksanakan oleh Menteri dan/atau menteri teknis perbaikan;

3. Pengawasan oleh masyarakat dilakukan terhadap barang dan/atau jasa yang bered ar di pasar;

4. Apabila hasil pengawasan sebagaimana dimaksud pada ayat (3) ternyata menyimpang dari peraturan perundang-undangan yang berlaku dan membahayakan konsumen, Menteri dan/atau menteri teknis mengambil tindakan sesuai dengan peraturan prundang-undangan yang berlaku;

5. hasil pengawasan yang diselesaikan masyarakat dan lembaga perlindungan konsumen swadaya masyarakat disebarluaskan kepada masyarakat dan dapat disampaikan kepada Menteri dan menteri teknis;

6. Ketentuan pelaksanaan tugas pengawasan sebagaimana dimaksud pada ayat (1), ayat (2), dan ayat (3) dutetapkan dengan Peraturan Pemerintah.

Dalam pasal ini jelaslah bahwa jalannya peraturan tentang perlindungan konsumen telah diawasi langsung oleh pemerintah, masyarakat, dan lembaga perlindungan konsumen swadaya masyarakat serta didukung dengan adanya lembaga peradilan umum.

Dalam perjanjian bisnis multi level marketing jika baik pihak Distributor maupun pihak konsumen melakukan suatu perbuatan yang merugikan pihak lainnya, maka pihak yang menimbulkan kerugian tersebut dapat dikenakan tuntutan atau ganti rugi akibat dari perbuatannya tersebut. Tetapi hingga saat ini baik Distributor maupun konsumen belum pernah melakukan perbuatanperbuatan yang menimbulkan kerugian bagi pihak lainnya. ${ }^{26}$

Dalam hal sengketa konsumen yang melanggar hak-hak konsumen, maka akan mencakup semua segi hukum, baik keperdataan, pidana maupun tata negara. Oleh karena itu tidak digunakan istilah "sengketa transaksi konsumen" karena hal tersebut hanya berkesan lebih sempit, yang hanya mencakup aspek keperdataan.

Menurut UUPK penyelesaian sengketa konsumen ternyata memiliki kekhasan. Sejak semula, para pihak yang berselisih khususnya dari pihak konsumen dapat menyelesaikan sengketa itu mengikuti beberapa lingkungan

${ }^{26}$ Tarmizi Yusuf, Op.Cit, h.121 


\section{Jurnal Ilmiah METADATA}

peradilan, misalnya peradilan umum, atau dengan menyelesaikan sengketa konsumen diluar pengadilan.

\section{Penyelesaian di Peradilan Umum}

Pasal 45 ayat (1) UUPK menyatakan :

"Setiap konsumen yang merugikan dapat menggugat pelaku usaha melalui lembaga yang bertugas menyelesaikan sengketa antara konsumen dan pelaku usaha atau melalui peradilan yang berada di lingkungan peradilan umum".

\section{Penyelesaian di Luar Pengadilan}

UUPK memberikan jalan alternatif dengan menyediakan penyelesaian sengketa diluar pengadilan. Dalam Pasal 45 ayat (4) UUPK menyebutkan : Jika telah dipilih upaya penyelesaian sengketa konsumen di luar pengadilan, gugatan melalui pengadilan hanya dapat ditempuh jika upaya itu dinyatakan tidak berhasil oleh salah satu pihak atau oleh para pihak yang bersengketa.

Ini berarti penyelesaian di pengadilan pun tetap di buka setelah para pihak gagal menyelesaikan sengketa mereka di luar pengadilan.

Secara radiksional, juga jelas apa yang di maksud dengan istilah "penyelesaian diluar pengadilan" ini adalah upaya perdamaian di antara mereka (konsumen dan produsen), atau juga termasuk penyelesaian melalui Badan Penyelesaian Sengketa Konsumen (BPSK).

Konsep dari Undang-undang Perlindungan Konsumen yang secara garis besar memberikan harapan baru bagi konsumen termasuk didalamnya juga konsumen dalam bisnis Multi Level Marketing. Dengan kata lain sanksi yang ada dalam UUPK juga sekaligus merupakan sanksi untuk sengketa konsumen dalam MLM dan juga diawasi langsung oleh pemerintah dan organ-organ yang ada dalam masyarakat. Seperti APLI yang merupakan wadah berkumpulnya para pelaku usaha MLM, yang bergandengan tangan dengan pemerintah untuk memberikan pengawasan langsung dalam bisnis MLM ini. Begitu pula dengan tujuan dari SK Menperidang Nomor. 7 Tahun 2000 yang didalamnya membahas juga tentang izin Usaha Penjualan Berjenjang (IUPB) yang mendukung pemerintah agar nantinya dapat bertindak bila terjadi pelanggaran hukum. 


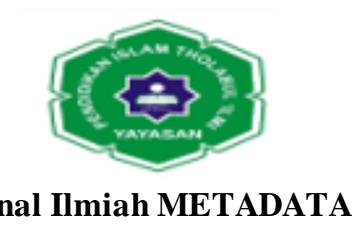

\section{KESIMPULAN}

Perlindungan terhadap pelanggaran hak-hak konsumen dalam bisnis Multi Level Marketing (MLM), maka Distributor sebagai pelaku usaha atas konsumen multi level marketing bertanggung jawab memberikan ganti terhadap barangbarang yang tidak sesuai atau rusak yang disebabkan kesalahan pihak perusahaan kepada konsumen, serta bertanggung jawab terhadap produksi yang dihasilkannya dan bertanggung jawab atas propesinya sebagai pelaku usaha, hal ini di dukung oleh pasal-pasal tentang kewajiban pelaku usaha yang terdapat dalam Pasal 1365 KUH Perdata dan Pasal 6 Undang-Undang Nomor 8 Tahun 1999 tentang Perlindungan Konsumen

Pertanggung jawaban pelaku usaha bisnis Multi Level Marketing (MLM) terhadap konsumennya apabila salah satu pihak wanprestasi baik pihak Distributor atau anggotanya (konsumen) melakukan perbuatan ingkar janji atau tidak memenuhi prestasi sebagaimana diperjanjikan, maka dapat dituntut untuk memberikan ganti rugi akibat dari perbuatan wanprestasi tersebut.

\section{DAFTAR PUSTAKA}

\section{A. Buku/Literatur}

Abdul Muis., Bunga Rampai Hukum Dagang, FH. USU Medan, 1990.

-----;Yayasan Sebagai Wadah Kegiatan Masyarakat, FH. USU, Medan, 1991. Abdulkadir Muhammad., Perjanjian Baku Dalam Praktek Perusahaan Perdagangan, PT. Citra Aditya Bhakti, Bandung, 1992

Allen Carmichael.1996, Network dan Multi Level Marketing, Pustaka Delapratasa, Jakarta

AZ. Nasution.1999, Hukum Perlindungan Konsumen, Daya Widya, Jakarta.

Buhari Alma.1998, Pengantar Bisnis, Al-Fabeta,Bandung

Gunawan Widjaya dan Ahmad Yani, 2003, Hukum Tentang Perlindungan Konsumen, PT.Gramedia Pustaka Utama, Jakarta

Husni Syawali dan Sri, Imaniyati, Neni, 2000, Hukum Perlindungan Konsumen, CV. Mandar Madju, Bandung.

IBR. Supancana.,2003, Hukum Perusahaan Suatu Telaah Yuridis Normatif, CV. Mitra Karya, Jakarta

Philip Kotler and Bary Armstrong., 1997, Dasar-Dasar Pemasaran (principle of Marketing), Prenhallindo, Jakarta. 


\section{당 \\ Jurnal Ilmiah METADATA}

Peter J. Clotheir.,1996, Meraup Uang Dengan Level Marketing, Gramedia Utama, Jakarta

Sudaryatmo.,1999, Hukum dan Advokasi Konsumen, PT. Citra Aditya Bhakti, Bandung.

Sidharta.,2000, Hukum Perlindungan Konsumen Indonesia, PT. Grasindo, Jakarta

Tarmizi Yusuf., 2000, Strategi MLM Secara Cerdas dan Halal, PT. Alex Media Komputindo, Jakarta.

Yusuf Shofie., Perlindungan Konsumen dan Instrumen-Instrumen Hukumnya, PT. Citra Aditya Bhakti,Bandung, 2000

Zumrotin K. Susilo., 1996, Penyambung Lidah Konsumen, YLKI, Jakarta

\section{B. Peraturan perundang-undangan}

Undang-Undang Nomor 8 Tahun 1999 tentang Perlindungan Konsumen.

\section{Jurnal}

Nurita, C., \& Lubis, M. (2019). TINJAUAN YURIDIS TINDAK PIDANA PEMILU DAN PROSES PENYELESAIANNYA BERDASARKAN UU NO. 8 TAHUN 2012 TENTANG PEMILIHAN UMUM WILAYAH SUMATERA UTARA. Jurnal Ilmiah METADATA, 1(2), 17-40.

Nurita, C., \& Lubis, M. (2019). TINJAUAN TERHADAP TINDAK PIDANA BERDASARKAN UU RI NO. 7 TAHUN 1996 TENTANG PANGAN (Studi Kasus Perkara No. 54/Pid.B/2003/PN.Mdn). Jurnal Ilmiah METADATA, 1(3), 106-126.

Syah, D. (2019). SUATU TINJAUAN HUKUM TENTANG BAGI HASIL ATAS TANAH PERTANIAN ANTARA PEMILIK TANAH DENGAN PETANI. Jurnal Ilmiah METADATA, 1(3), 127-146.

Handayani, K., \& Siregar, M. (2019). TINJAUAN KEKUATAN PEMBUKTIAN DIGITAL SIGNATURE DALAM SENGKETA PERDATA DITINJAU DARI UU NO. 11 TAHUN 2008 TENTANG INFORMASI DAN TRANSAKSI ELEKTRONIK. Jurnal Ilmiah METADATA, 1(3), 168-189. 